\title{
MENJAMIN MUTU PELAKSANAAN PEMBELAJARAN E-LEARNING
}

\section{Oleh: Agus Hery Supadmi Irianti \\ Dosen TI-FT-UM}

\begin{abstract}
ABSTRAK
Pentingnya pendidikan bagi seluruh warga negara tertuang dalam Pasal 28B Ayat (1) yaitu bahwa setiap orang berhak mengembangkan diri melalui pemenuhan kebutuhan dasarnya, berhak mendapatkan pendidikan dan mendapatkan manfaat dari ilmu pengetahuan dan teknologi, seni dan budaya demi meningkatkan kualitas hidupnya dan kesejahteraan umat manusia. Sudah barang tentu peningkatan kualitas pendidikan menyesuaikan dengan kemajuan teknologi, tentu saja disini tidak kalah adalah peran dosen sebagai tenaga pengajar dalam memanfaatkan kemajuan teknologi khususnya pemanfaatan internet. Perkembangan teknologi saat ini begitu pesat, dampak perkembangan teknologi ini telah menyentuh beberapa bidang diantaranya bidang pendidikan. Salah satu bidang yang tersentuh dampak perkembangan teknologi ini adalah dunia pendidikan. Sebagai sebuah sumber informasi yang hampir tak terbatas, maka jaringan internet memenuhi kapasitas dijadikan sebagai salah satu sumber pembelajaran dalam dunia pendidikan. ? E-learning adalah suatu pembelajaran yang berbasis web yang memungkinkan siapapun bisa mempelajarainya melalui jaringan internet, dimana dan kapanpun serta terasa menyenangkan, mudah dan murah.. Di satu sisi pemanfaatan teknologi dalam pembelajaran di dorong dan digiatkan akan tetapi pada pelaksanaan evaluasi pembelajaran belum dimunculkan instrument yang dapat mengontrol pelaksanaan pembelajaran berbasis internet itu sendiri. Saat ini salah satu instrument evaluasi penyelenggaraan pembelajaran adalah masih dilihat pada tingkat kehadiran dosen dan mahasiswa, tentunya ini sudah tidak dapat digunakan lagi sebagai ukuran yang dapat menjamin penyelenggaraan pembelajaran khususnya model pembelajaran e-learning. Untuk menjamin mutu penyelenggaraan model pembelajaran e-learning diperlukan instrument lain sebagai pengganti absensi kehadiran dosen. berupa data mahasiswa yang mengunjungi situs di blog dosen, miling list sebagai sarana mengirim tanggapan atau pengumpulan tugas mahasiswa melalui email.
\end{abstract}

Kata Kunci: Penjaminan Mutu, E-learning 


\section{PENDAHULUAN}

Undang-undang Nomor 20 Tahun 2003 tentang Sistem Pendidikan Nasional menggariskan bahwa pendidikan adalah usaha sadar dan terencana untuk mewujudkan suasana belajar dan proses pembelajaran agar peserta didik secara aktif mengembangkan potensi dirinya agar dapat memiliki kekuatan spiritual keagamaan, pengendalian diri, kepriba dian, kecerdasan, akhlak mulia, serta keterampilan yang diperlukan dirinya, masyarakat, bangsa dan negara. Sistem pendidikan nasional adalah keseluruhan komponen pendidikan yang saling terkait secara terpadu untuk mencapai tujuan pendidikan nasional. Pendidikan nasional berfungsi mengembangkan kemampuan dan membentuk watak serta peradaban bangsa yang bermartabat dalam rangka mencerdaskan kehidupan bangsa, bertujuan untuk berkembangnya potensi peserta didik agar menjadi manusia yang beriman dan bertakwa kepada Tuhan Yang Maha Esa, berakhlak mulia, sehat, berilmu,cakap, kreatif, mandiri, dan menjadi warga negara yang demokratis serta bertanggung jawab. Peningkatan akses masyarakat terhadap pendidikan yang lebih berkualitas merupakan mandat yang harus dilakukan bangsa Indonesia sesuai dengan tujuan negara Indonesia yang tertuang dalam Pembukaan UUD 1945 yaitu untuk melindungi segenap bangsa dan seluruh tumpah darah Indonesia, mencerdaskan kehidupan bang sa, memajukan kesejahtera an umum dan ikut melaksanakan ketertiban dunia yang berdasarkan kemerdekaan, perda maian abadi dan keadilan sosial. Lebih lanjut dalam Batang Tubuh UUD 1945 diamanatkan pentingnya pendidikan bagi seluruh warga negara seperti yang tertuang dalam Pasal 28B Ayat (1) yaitu bahwa setiap orang berhak mengembangkan diri melalui pemenuhan kebutuhan dasarnya, berhak mendapatkan pendidikan dan mendapatkan manfaat dari ilmu pengetahuan dan teknologi, seni dan budaya demi meningkatkan kualitas hidupnya dan kesejahteraan umat manusia. Sudah barang tentu peningkatan kualitas pendidikan menyesuaikan dengan kemajuan teknologi, tentu saja disini tidak kalah adalah peran dosen sebagai tenaga pengajar dalam memanfaatkan kemajuan teknologi khususnya pemanfaatan internet.

Perkembangan teknologi saat ini begitu pesat, dampak perkembangan teknologi ini telah menyentuh beberapa bidang diantaranya bidang pendidikan. Salah satu bidang yang tersentuh dampak perkembangan teknologi ini adalah dunia pendidikan. Sebagai sebuah sumber 
informasi yang hampir tak terbatas, maka jaringan internet memenuhi kapasitas dijadikan sebagai salah satu sumber pembelajaran dalam dunia pendidikan. Bahkan beberapa perguruan tinggi ternama, mencanangkan lahirnya sistem pembelajaran yang berbasiskan teknologi jaringan ini, seperti lahirnya konsep tentang distance learning, web-based education, dan e-learning, IT, yang kalau ditinjau dari implementasinya mempunyai wujud yang hampir sama, yaitu memanfaatkan fasilitas jaringan internet sebagai salah satu sarana dan media dalam pendidikan dan pengajaran. Apa sesungguhnya e-learning itu? E-learning adalah suatu pembelajaran yang berbasis web yang memungkinkan siapapun bisa mempelajarainya melalui jaringan internet, dimana dan kapanpun serta terasa menyenangkan, mudah dan murah. Pembelajaran berbasis web (E-learning) pada hakikatnya adalah perkembangan dari konsep sistem belajar jarak jauh (Distance learning). Sistem pembelajaran berbasis web ini bisa tejadi karena perkembangan yang pesat dari tiga bidang, yaitu; bidang pembelajaran jarak jauh, pembelajaran dengan menggunakan teknologi komputer, dan perkembangan bidang teknologi internet. Pendidikan pada dasarnya merupakan suatu proses komunikasi informasi dari pendidik kepada peserta didik yang berisi informasi-informasi pendidikan, yang memiliki unsur pendidik sebagai sumber informasi, media sebagai sarana penyajian ide, gagasan dan materi pendidikan serta peserta didik itu sendiri (Oetomo, 2004). Beberapa bagian unsur ini mendapat sentuhan media teknologi informasi, sehingga mencetuskan lahirnya ide tentang e-learning Melihat perkembangan fenomena ini, akan sangat tertinggal dunia pendidikan kita, jika tidak bisa memanfaatkan teknologi internet. Walaupun belum akan menyelenggarakan pengajaran maupun pendidikan berbasiskan internet, setidaknya dosen mampu dan menganjurkan pemanfaatan resources yang ada di internet sebagai salah satu sumber pembelajaran maupun bahan pengajaran, bahkan media pembelajaran.

Dosen dalam melaksanakan tugasnya tidak bisa lepas dari Tri Dharma Perguruan Tinggi, yaitu melaksanakan pengajaran, penelitian dan pengabdian pa da Masyarakat. Untuk melaksanakan dharma pertama yaitu pengajaran tentu ti dak dapat mengabaikan kemajuan tek nologi baik dampak dan manfaat yang terkait dengan tugas-tugas dosen dalam melaksanakan pengajaran. Kalau kita dapat memanfaatkan kemajuan teknologi dalam kegiatan pengajaran tentunya akan memberikan banyak kemudahan juga kemutakhiran serta tidak terikat oleh waktu dan ruang yang selama ini selalu menjadi 
batas pelaksanaan pengajaran. Pesatnya kemajuan teknologi jika kita manfaatkan untuk kegiatan yang positif akan mem bantu dosen dalam melaksanakan tugastugasnya. Banyak keuntungan yang dapat diperoleh jika dosen memanfaatkan internet baik sebagai media, sarana ataupun sumber pembelajaran. Adapun keuntungannya adalah: menerapkan kemajuan teknologi dalam proses belajar mengajar, pelaksanakan dapat dilaksana kan tanpa batas ruang dan waktu, artinya dimanapun dosen berada dapat melak sanakan tugas belajar mengajar, termasuk mengontrol tugas-tugas yang diberikan kepada mahasiswa, memudahkan maha siswa dalam mencari sumber-sumber belajar yang relevan, dll.

Salah satu arah kebijakan Um adalah ikut berpartisipasi aktif dalam transformasi social budaya dan sumber daya manusia yang cerdas dan kompetitif , serta mampu menguasai dan mengem bangkan IPTEKS untuk meningkatkan kesejahteraan umat manusia ( Kebijakan Akademik UM, 2008). Peningkatan mutu pendidikan UM didasarkan pada 5 pilar kebijakan pengem bangan proses pembelajaran, diantaranya : penerapan teknologi infor masi dalam perkuliahan dan pembudayaan multi media dalam perkuliahan serta penggunaan internet sebagai sumber belajar (Manual Mutu
Sistem Penjaminan Mutu Akademik $\mathrm{UM}, 2008)$

\section{PERMASALAHAN}

Keberhasilan mutu pendidikan sangat tergantung dari keberhasilan proses belajar-menga jar yang merupakan sinergi dari komponen-komponen pendidikan baik kurikulum tenaga pen didikan, sarana prasarana, sistem pengelolaan, maupun berupa faktor lingkungan alamiah dan lingkungan sosial, dengan peserta didik sebagai subjeknya. Proses belajar mengajar sebagai sistem dipengaruhi oleh berbagai faktor. Salah satu di antaranya adalah tenaga pengajar yang merupakan pelaksana utama pendidikan di lapangan. Kualitas tenaga pengajar baik kualitas akademik maupun non akademik juga ikut mempe ngaruhi kualitas pembelajaran. Faktor lainnya yang tak kalah pentingnya dalam menentukan keberhasilan kegiatan belajarmengajar adalah sumber belajar. Dalam rangka mengupayakan peningkatan kualitas program pembelajaran perlu dilandasi dengan pandangan sistematik terhadap kegiatan belajar-mengajar, yang juga harus didukung dengan upaya pendayagunaan sumber belajar di antara nya internet. Pengertian internet itu sendiri adalah jaringan (Network) komputer terbe sar di dunia. Jaringan berarti kelompok komputer yang dihubungkan bersama, sehingga dapat berbagi pakai informasi 
dan sumber daya (Shirky, 1995:2). Dalam internet terkandung sejumlah standar untuk melewatkan informasi dari satu jaringan ke jaringan lainnya, sehingga jaringan-jaring an di seluruh dunia dapat berkomunikasi. Sidharta (1996) memberikan definisi yang sangat luas terhadap pengertian internet. Internet adalah forum global pertama dan perpustakaan global pertama dimana setiap pemakai dapat berpartisipasi dalam segala waktu. Karena internet merupakan perpustakaan global, maka pemakai dapat memanfaatkannya sebagai sumber belajar. Secara umum dapat dikatakan bahwa internet adalah suatu istilah yang digu nakan untuk menggambarkan saling hubungan antar jaringan-jaringan kom puter yang sedemikian rupa sehingga memungkinkan komputer-komputer itu berkomunikasi satu sama lain. Di satu sisi pemanfaatan teknologi dalam pembe lajaran di dorong dan digiatkan akan tetapi pada pelaksanaan evaluasi pembelajaran belum dimunculkan instrument yang dapat mengontrol pelaksanaan pembelajaran berbasis internet itu sendiri. Saat ini salah satu instrument evaluasi penyelenggaraan pembelajaran adalah masih dilihat pada tingkat kehadiran dosen dan mahasiswa, tentunya ini sudah tidak dapat digunakan lagi sebagai ukuran yang dapat menjamin penyelenggaraan pembelajaran khususnya model pembelajaran $e$-learning. Dengan $e$ learning bisa saja terjadi perkuliahan tidak diruang kelas dan waktu sesuai jadual yang ada, akan tetapi bisa saja pembelajaran yang menggunakan fasilitas internet diselenggarakan dengan ruang yang terpisah bahkan dosen di Jakarta mahasiswa diMalang atau sebaliknya. Namun demikian tidak bisa juga melaksanakan pembelajaran berbasis Internet tetapi tidak bisa dilacak kebenaran penyelenggaraan atau tidak mempertanggung jawabkan pelaksanaan pembelajaran. Tentu saja ini juga dilematis. Bagaimana menjamin pelaksanaan model pembelajaran $e$ learning?

\section{PEMECAHAN MASALAH}

Untuk menjamin mutu penyelenggaraan model pembelajaran e-learning diperlukan instrument lain sebagai pengganti absensi kehadiran dosen.karena e-learning dapat dilakukan di luar kampus.Instrumen tersebut dapat berupa data mahasiswa yang mengunjungi situs di blog dosen, miling list sebagai sarana mengirim tanggapan atau pengumpulan tugas mahasiswa melalui email. Untuk itu materi yang disajikan dilengkapi dengan tugas atau tanggapan mahasiswa sehingga dapat dikontrol bahwa mahasiswa benar benar dapat dipastikan telah membaca materi di blog yang ditentukan. 
PUSTAKA

BPM UM. 2008. Kebijakan Akademik UM

BPM UM. 2008. Manual Mutu Sistem Penjaminan Mutu Akademik UM,

Oetomo, B.S.D dan Jarot Priyogutomo, Kajian Terhadap Model e-Media dalam Pembangunan Sistem e-Education, Makalah Seminar Nasional Informarika
2004 di Universitas Ahmad Dahlan Yogyakarta pada 21 Februari 2004.

Shirky, C.1995. Internet lewat E-mail. Jakarta: PT. Alex Media Komputindo.

Sidharta, L. 1996. Internet: Informasi Bebas Hambatan 1. Jakarta: PT Alex Media Komputindo.

Sisdiknas, 2003 


\title{
SERTIFIKAT
}

No. $1317 /$ H.32.5/DT/2009

\author{
Diberikan kepada \\ Agus Hery Supadmi Irianti \\ Institusi \\ Universitas Negeri Malang \\ Atas keikutsertaanya sebagai \\ Pemakalah
}

dalam Seminar Nasional Electrical, Informatic, and it's Education 2009 yang diselenggarakan oleh Jurusan Teknik Elektro Fakultas Teknik Universitas Negeri Malang pada tanggal 25 Juli 2009.

\footnotetext{
Keynote Speaker :

- Kepala Pusat Data Depkominfo, Dr. Ir. Ari Santoso, DEA.

- Direktur SEAMOLEC, Dr. Ir. Gatot Mari Priowirjanto

- Kepala Bldang Pendidikan Menengah Kejuruan \&

Perguruan Tinggi Jawa Timur, Drs. Widjil Saptadi, M.M.

- KRMT Roy Suryo
}

Malang, 25 Juli 2009 Bekan Fakultas Teknik

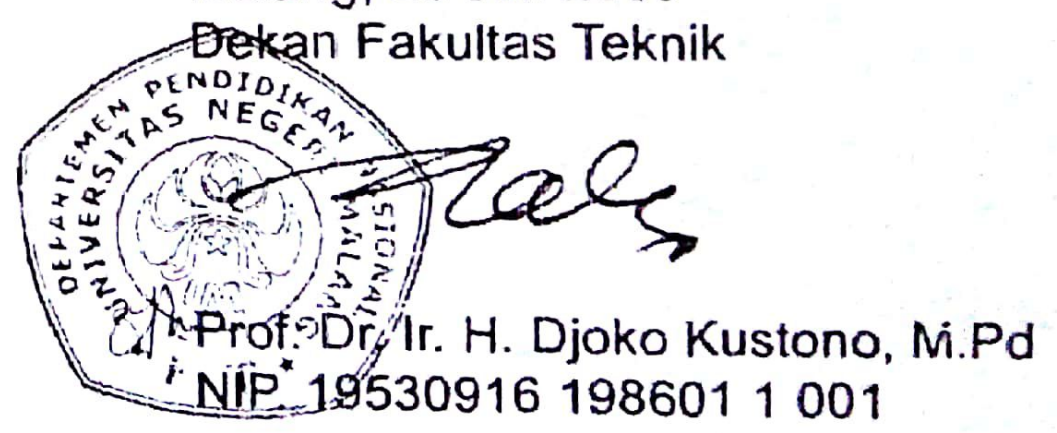

